\title{
A SYSTEMATIC LITERATURE REVIEW OF METHODOLOGIES USED FOR THE DESIGN OF SERIOUS GAMES. A COMPARATIVE ANALYSIS
}

\author{
Juan Carlos Sandí Delgado ${ }^{1}$, \& Patricia Alejandra Bazán ${ }^{2}$ \\ ${ }^{1}$ Guápiles-Atlantic Branch, Universidad de Costa Rica (UCR), Limón (Costa Rica) \\ ${ }^{2}$ Faculty of Informatics, Universidad Nacional de La Plata (UNLP), Buenos Aires (Argentina)
}

\begin{abstract}
This article of systematic literature review presents the analysis of a series of methodological proposals, suggested for the design of educational video games. Nine different methodologies are analyzed. As part of the analysis, criteria are defined to describe and compare them, linked with the possibilities they have for the design of serious games. Criteria include: requirements elicitation and specification, pedagogical intention, pedagogical and ludic objectives definition, educational level and target public, roles identification, feedback type, user experiences analysis, objectives and methodologies validation. Main results indicate the following. 1) It is of vital importance, in the initial phase of a methodology design to incorporate the requirements elicitation and specification, as well as to define and assign roles of the different parties involved in the game production, all of this jointly and by consensus. 2) The definition of pedagogical objectives is closely related to the context use and it is important that it be done in the initial stage and then asses the game quality in the final stage. 3) It is important to incorporate the definition of pedagogical elements in the design. They will be helpful to assess the efficiency, learning and the user experience in relation with the interaction with the game. In addition, these pedagogical elements will facilitate the development of a quantitative record of learning to know the process and its quality by the user. It is concluded that the set of methodologies analyzed provide information in regards to the considerations when proposing a methodology for the design of a serious games. As a future work, there will be a methodological proposal, which will facilitate the integration of the aspects identified through the revision of the methodologies analyzed to guide systematically the design process of a serious game, specifically targeted to the teaching of digital competencies.
\end{abstract}

Keywords: Serious game, serious games design, methodologies, comparative analysis, higher education.

\section{Introduction}

Serious games are software pieces designed with a focus beyond entertainment or amusement, to include an explicit educational purpose and to be used in teaching and behavior change in different knowledge areas, health, government, NGOs, economy, military training, education and skills and competencies development (Michael \& Chen, 2006). Due to their playful and pedagogical component they have become more important in the academic field (Boyle et al., 2016). In this context, this work analyses a series of methodologies designed to guide the software development for educational serious games to identify representative characteristics that contribute to the development of a methodology oriented to create serious games.

The results of this investigation contribute to define methodologies oriented to the design of serious games in general and of educational games in particular. The article is organized as follows. Section 2: Background; Section 3: methodology, which includes the analysis criteria and the methodologies selected for the study; Section 4: main results obtained after applying the assessment criteria, and finally Section 5: main conclusions and future work.

\section{Background}

It was 1970 when the concept of serious games was first mentioned by Abt (1970). Lately, the term as well as the author have been referenced in different investigations (Marcano, 2008; Michael \& Chen, 2006; Sandí, 2019; Sandí \& Bazán, 2019), among others. Serious games offer a variety of possibilities to form and/or acquire new skills in different knowledge areas through games, instruction, simulation, training or education and mainly facilitate pleasure and motivation (Sandí \& Sanz, 2020). 
In this context, serious games could be used to maximize training processes due to their characteristics related to the educational field in regards to motivation, interactivity, active students and teacher's participation, where the playful and pedagogical elements promote learning based on feedback (Boyle et al., 2016). The definition of serious games adopted for this investigation is: A serious game could be defined as that one that focuses not only on entertainment or amusement, but also on an explicit educational purpose and carefully thought. It can be used to maximize different areas of knowledge, facilitate learning, support instruction processes, promote attitude or behavior changes, generate emotions, maximize skills and/or competencies acquisition, among others. Its main characteristic is that it is attractive, interactive, entertaining-dynamic, motivator, challenging, easy to use, it stimulates cooperation, reasoning and critical thinking.

\section{Methodology}

The investigation was developed through descriptive design and with a qualitative methodological approach through a systematic revision of literature, following the protocol proposed by Kitchenham et al. (2009). To comply with the study objective, 3 investigation questions were defined: IQ1. How is the concept of serious games defined? IQ2. What methodologies have been used for the design of serious games? What antecedents exist in this regard? IQ3. What methodological aspects are considered in the literature to develop serious games? IQ's were defined as a guide to contextualize and define the concept of serious games and to identify methodologies that have been developed to design educational serious games, following the investigation criteria detailed ahead. The search strategy used to find the primary studies related to serious games and development methodologies consisted of inquiries in different databases of scientific and academic data, such as IEEE Xplore Digital Library, ScienceDirect and SCOPUS, which were selected due to their availability and access to the information required. Then, key words were defined and then search strings which facilitated the location of primary studies. Then, the analysis criteria were defined and the methodologies compilation and description were done. Lastly, results were given based on the criteria applied.

\subsection{Definition of analysis criteria}

Literature revision evidences the use of different types of methodologies/processes for the design of serious games which vary depending on the author or investigator who presents them and depending also on the objective of each investigation. Considering this, criteria were defined to focus the analysis homogeneously among a group of methodologies. Criteria selection was based on (Cano, 2016; Cano, Muñoz, Collazos, González, \& Zapata, 2016) and the study objective aims at describing methodologies that have been used for the design of serious games, paying special attention to aspects (distinctive features) that have to be considered for their design. To describe and analyze the methodologies or processes, 4 categories were defined with different criteria analysis each: A) General aspects - Criteria in this category coincide with the methodologies to be analyzed. Indicators facilitate identifying country of origin and educational level. B) Design aspects - Criteria in this category are used to analyze the ways in which the aspects of methodologies/processes design are defined. The purpose is to identify the basis of the proposals, if an elicitation is done and users requirements are defined, to know if roles definition is included, software reuse and prototypes design. C) Methodological-Pedagogical aspects - Criteria in this category allow identification of addressees, pedagogical intention and definition of pedagogical/playful objectives of the methodology. D) Analysis aspects - This category includes the criteria which analyze the methodology development activity. Since this is a methodological proposal or of processes for the design of serious educational games, the purpose is to know the process or method used to validate the objectives of the proposal, as well as the assessment of the user experiences, and finally the use of quantifiable results to assess the quality of learning of the user.

\subsection{Methodology collection}

Literature revision allowed the identification of a group of methodologies for the design of serious games. Nine of them have been selected for the analysis. Following each of them are briefly described:

- EMERGO (Nadolski et al., 2008) includes 5 stages (analysis, design, development, implementation and assessment) and tools as a guide for the design of serious games based on scenarios.

- EDoS (Environment for the Design of Serious Games) (Tran, George, \& Marfisi-schottman, 2010) environment mainly used in the design stage and part of it during the production stage of serious games. It is used after the stage of user requirements definition and it offers as a final product a structured and formal scenario to be executed by the game motor in the final stage. It includes 3 models (pedagogical objectives, pedagogical scenarios and CTT 
(Concur Task Tree) tasks) which offer a series of interactive tools to facilitate users performing tasks in a visual and easy way.

- LEGADEE (LEarning GAme DEsign Environment) (Marfisi-Schottman, 2012; Marfisi-Schottman, George, \& Tarpin-Bernard, 2010). Its purpose is to serve as a guide to develop serious games to maximize the training of professional skills. It consists of 7 stages (pedagogical objectives, game model selection, general description of the scenario and virtual environment, reusable software, scenario description, pedagogical quality control and subcontractor specification).

- SAVIE (Sauvé, 2009) interactive pedagogical design model to develop generic serious games to maximize on line learning. It includes 5 stages (analysis, design, technical development, formative assessment of the generic game, summarized assessment of the games created with the generic Shell of the game). Teachers can create different serious games using the same base or structure which can be accessed by students through Internet. For instance, it was used to modify the original structure of the game "Parcheesi" to change some of the rules of the game to make it easier to use and to add more learning activities. Also, Parcheesi was used to develop another game on line in which the player can acquire knowledge related with asthma prevention.

- DODDEL (Document-Oriented Design and Development of Experiential Learning) (McMahon, 2009). It is used by designers and developers. It can be documented and guides can be developed to help with the design and development of serious games. It includes 4 development stages (situation analysis, design proposal, documentation design and production documentation) and a level of assessment (prototypes creation) to balance games designs.

- VGSCL (Video Game - Supported Collaborative Learning) (Padilla-Zea, 2011). It proposes a process to develop educational videogames including a balance between 3 factors: learning, amusement and collaborative learning activities. The methodology was designed from a model based approach to execute explicit abstractions of independent systems of the subsequent implementation to facilitate flexibility which will make it easier to maintain and reuse the system as well as the information stored in these models. It was used to develop the game "Nutri-Galaxy" which helps high School students (11 to 12 years) maximize collaborative learning.

- MECONESIS (MEtodología para la CONcepción de juEgos Serios para nIñoS con discapacidad auditive-Methodology to Conceive Serious Games for Hearing Impaired Children) (Cano, 2016). It proposed the development of serious games by adapting different models and tools. It is structured in 4 stages (Analysis, Pre-production, Production and Post-production) and 7 models (analysis, user, adaptation, pedagogical objectives, tasks, scenarios and validation). It was used to develop the serious game "Lectoescritura con Fitzgerald" (Literacy with Fitzgerald) to help high school hearing impaired students (12 to 15 years) maximize learning (literacy).

- MPIu+a (Modelo de Proceso de la Ingeniería de la Usabilidad y de la Accesibilidad Usability and Accessibility Engineering Process Model) (Granollers, 2004). It is used to design interactive systems focused on the user, integrating software engineering with the principles of usability and accessibility to guide in the implementation of interactive systems. It includes 6 stages (requirements analysis, design, implementation, launching, prototyping and assessment). It was used to develop different types of prototypes (low-fidelity or high fidelity).

- MPDSG (Modelo de Proceso de Desarrollo para Serious Games - Development Process Model for Serious Games) (Evans, Spinelli, Zapirain, Massa, \& Soriano, 2016). It proposes a processes model to guarantee the quality of the game, playability and player immersion. It uses a combination of 3 aspects: pedagogical, game and software. The methodology was designed for the development of serious games that maximize the acquisition of competencies for the XXI Century. It was used to develop the game "Power Down the Zombies" in which high school students (Fourth year) assess the environmental and social impact of the technological use of energy while critically reflecting on the natural resources use.

\section{Results analysis based on assessment criteria}

\subsection{General Aspects}

The country in which the investigation is developed shows that the development of methodological proposals has focused on Europe with a 56\%, followed by America with a 33\%, and last 
by Asia with a $11 \%$. Regarding the educational level criteria, $56 \%$ of the methodologies are mainly used in higher education/university and $44 \%$ in high school.

\subsection{Design aspects}

Sixty-seven per cent of the methodologies analyzed consider that the final user has a leading role during the design due to the characteristics of the serious games (pedagogical and playful). In this context, the methodological proposal should be grounded through the user-centered design. Forty-four percent of the methodologies reviewed show that it is important to incorporate the elicitation and user requirements specification in the initial stage of the methodology design. Fifty-six percent of the methodologies consider definition and role assignment of the different actors involved in the game design, highlighting the role of the teacher (pedagogical expert). Also, 56\% consider important to include the role of the final user. It is recommended to implement them jointly and by consensus among the different actors involved. Fifty-six percent of the methodologies consider important to include in the methodology design components flexibility and reuse (software reuse). Sixty-seven percent of the methodologies consider important to include in the methodological design the creation of prototypes because they facilitate reduction and correction of possible mistakes that could occur during the game development.

\subsection{Methodological-Pedagogical aspects}

Addressee analysis shows that $78 \%$ of the methodologies reviewed prove that they were designed to be used by higher education faculty to maximize different skills and/or competencies in students. Pedagogical intention: the most important result is related with the total of methodologies investigated which focus on maximizing learning, as well as the development of specific competencies and/or skills: cognitive, professional, generic, among others. Pedagogical-playful objectives analysis shows that the total of methodologies analyzed agree that this aspect has to be included in the design proposals. Objectives clearly defined favor the definition of competencies and learning to be obtained or maximized in the final user, as well as to verify its compliance (Cano, 2016).

\subsection{Aspects of analysis}

Seventy-eight percent of the methodologies consider important to include objectives validation during all the development stages of the serious game. This task has been developed through data entry tests, monitoring to validate the learning process and questionnaires. Sixty-seven percent of the methodologies analyzed consider important to include the assessment of the user experiences during the design of serious games. This activity is done in the methodologies studied through prototypes, feedback analysis, interviews and questionnaires. Quantifiable results: 78\% of the methodologies studied do not consider them; however, the other $22 \%$ do it through interviews and questionnaires to obtain qualitative and quantitative results.

\section{Conclusions and future work}

The purpose of this article is to do a comparative analysis of the different methodologies developed to design serious educational games to identify distinctive characteristics that contribute to the design of a methodology oriented to the development of serious games. The study is part of a doctoral research related to the design of a methodological and architectural proposal to guide step by step the design of serious games oriented to the training of technological competencies.

The investigation made it evident that there are efforts to consolidate methodologies oriented to the development of educational serious games; however, the results obtained verify that the methodologies analyzed focus only in offering different recommendations related with the design of a serious game (Cano, 2016; Padilla-Zea, 2011). Literature revision does not allow to specifically identify a methodological proposal to guide step by step the process to develop educational serious games and particularly oriented to maximize technological competencies. Nevertheless, it is concluded that the group of methodologies analyzed constitute a good support and contribute to the task of analyzing the distinctive characteristics that a methodological proposal should include for the design of serious games oriented to maximize technological competencies.

\section{Acknowledgements}

The research was partially funded by the Office of International Affairs and External Cooperation of the University of Costa Rica (UCR), Costa Rica. 


\section{References}

Abt, C. C. (1970). Serious Games. New York: Viking Press.

Boyle, E. A., Hainey, T., Connolly, T. M., Gray, G., Earp, J., Ott, M., Lim, T., Ninaus, M., Ribeiro, C., \& Pereira, J. (2016). An update to the systematic literature review of empirical evidence of the impacts and outcomes of computer games and serious games. Computers \& Education, 94, 178-192. doi:10.1016/j.compedu.2015.11.003

Cano, S. P. (2016). Propuesta Metodológica para el Diseño de Juegos Serios para Niños con Implante Coclear (Tesis doctoral, Universidad del Cauca, Cauca, Colombia). Retrieved from http://www.unicauca.edu.co/doctoradoce/publicaciones/Monografia_Cano.pdf

Cano, S. P., Muñoz, J., Collazos, C. A., González, C. S., \& Zapata, S. (2016). Toward a methodology for serious games design for children with auditory impairments. IEEE Latin America Transactions, 14(5), 2511-2521. doi:10.1109/TLA.2016.7530453

Evans, F., Spinelli, A. T., Zapirain, E. A., Massa, S. M., \& Soriano, F. (2016). Proceso de desarrollo de Serious Games. Diseño centrado en el usuario, jugabilidad e inmersión. Paper presented at the III Congreo Argentino de Ingeniería, Chaco, Argentina. Retrieved from https://www.researchgate.net/publication/326156974_proceso_de_desarrollo_de_serious_games_d iseno centrado en el usuario jugabilidad_e inmersion

Granollers, $\overline{\mathrm{T}}$. (2004). MPiu + a. Una Metodología que integra la ingeniería del software, la interacción persona-ordenador y la accesibilidad en el contexto de equipos de desarrollo multidisciplinares (Tesis doctoral, Universitat de Lleida, Lleida, España). Retrieved from https://www.tdx.cat/handle/10803/8120\#page=1

Kitchenham, B., Brereton, O. P., Budgen, D., Turner, M., Bailey, J., \& Linkman, S. (2009). Systematic literature reviews in software engineering - A systematic literature review. Information and Software Technology, 51(1), 7-15. doi:10.1016/j.infsof.2008.09.009

Marcano, B. (2008). Juegos Serios y Entrenamiento en la Sociedad Digital. Revista Electrónica Teoría de La Educación. Educación y Cultura En La Sociedad de La Información, 9(3), 93-107. Retrieved from http://dialnet.unirioja.es/servlet/articulo?codigo=2778746\&info=resumen

Marfisi-Schottman, I. (2012). Méthodologie, modèles et outils pour la conception de Learning Games (Tesis doctoral, L'institut National des Sciences Appliquées de Lyon, Villeurbanne, Francia). Retrieved from http://tel.archives-ouvertes.fr/tel00762855/\%5Cnhttp://liris.cnrs.fr/legadee/articles/Marfisi_theseManuscrit_2012.pdf

Marfisi-Schottman, I., George, S., \& Tarpin-Bernard, F. (2010). Tools and Methods for Efficiently Designing Serious Games. Paper presented at the 4th Europeen Conference on Games Based Learning, Copenhagen, Denmark. Retrieved from http://free.iza.free.fr/articles/ECGBL-iza.pdf

McMahon, M. (2009). Using the DODDEL model to teach serious game design to novice designers. In R. J. Atkinson \& C. McBeath (Eds.), Same places, different spaces: Proceedings Proceedings of Ascilite 2009 (pp. 646-653). Auckland, New Zealand. Retrieved from http://www.ascilite.org/conferences/auckland09/procs/

Michael, D., \& Chen, S. (2006). Serious Games: Games That Educate, Train, and Inform. Massachusetts, United States: Thomson Course Technology.

Nadolski, R. J., Hummel, H. G., van den Brink, H. J., Hoefakker, R. E., Slootmaker, A., Kurvers, H. J., \& Storm, J. (2008). EMERGO: A methodology and toolkit for developing serious games in higher education. Simulation \& Gaming, 39(3), 338-352. doi:10.1177/1046878108319278

Padilla-Zea, N. (2011). Metodología para el diseño de videojuegos educativos sobre una arquitectura para el análisis del aprendizaje colaborativo (Tesis doctoral, Universidad de Granada, Granada, España). Retrieved from http://hdl.handle.net/10481/19440

Sandí, J. C. (2019). Juegos serios para la indagación de competencias tecnológicas que puedan integrarse en la práctica pedagógica del profesorado. Una propuesta de aplicación en la Sede del Atlántico de la Universidad de Costa Rica (UCR). TE\&ET. Revista Iberoamericana de Tecnología En Educación y Educación En Tecnología, (23), 103-105. doi:10.24215/18509959.23.e13

Sandí, J. C., \& Bazán, P. A. (2019). Educational Serious Games as a Service: Challenges and Solutions. Journal of Computer Science and Technology, 19, 66-80. doi:10.24215/16666038.19.e07

Sandí, J. C., \& Sanz, C. V. (2020). Juegos serios para potenciar la adquisición de competencias digitales en la formación del profesorado. Revista Educación, 44(1), 1-18. doi:10.15517/REVEDU.V44I1.37228

Sauvé, L. (2009). Design tools for online educational games: Concepts and application. In Z. Pan, A. D. Cheok, \& W. Müller (Eds.), Transactions on Edutainment II: Vol. LNCS 5660. (pp. 187-202). Liverpool, United Kingdom: Springer. doi:10.1007/978-3-642-03270-7_9

Tran, C. D., George, S., \& Marfisi-schottman, I. (2010). EDoS: An authoring environment for serious games design based on three models. Paper presented at the 4th Europeen Conference on Games Based Learning, Copenhagen, Denmark. Retrieved from https://www.researchgate.net/publication/268379008_EDoS_An_authoring_environment_for_seri ous_games_design_based_on_three_model 